\title{
Correction to: Long non-coding RNA UCA 1 promotes malignant phenotypes of renal cancer cells by modulating the miR-182-5p/DLL4 axis as a ceRNA
}

Wei Wang ${ }^{1 \dagger}$, Wentao $\mathrm{Hu}^{2+}$, Ya Wang $^{3+}$, Yong An ${ }^{1}$, Lei Song ${ }^{4}$, Panfeng Shang ${ }^{1^{*}}$ and Zhongjin Yue ${ }^{1 *}$

\section{Correction to: Mol Cancer 19, 18 (2020)}

https://doi.org/10.1186/s12943-020-1132-x

Following publication of the original article [1], minor errors were identified in the images presented in Figs. 3, 4, and 6; specifically:

.Fig. 3d - miR-182-5p inhibitor images for Hoechst, Edu and Merge (bottom row)

.Fig. $4 \mathrm{a}$ - shUCA1 at $0 \mathrm{~h}$ (bottom left panel)

.Fig. $6 \mathrm{i}-\mathrm{shNC}+\mathrm{NC}$ images for Hoechst, Edu and Merge (top row)

The authors provided the journal with the original data files. The corrected figures are provided here. The correction does not have any effect on the results or conclusions of the paper. The original article has been corrected.

\section{Author details}

'Department of Urology, Institute of Urology, Gansu Nephro-Urological Clinical Center, Key Laboratory of Urological Diseases in Gansu Province, Lanzhou University Second Hospital, Lanzhou 730030, Gansu, China. ${ }^{2}$ School of Radiation Medicine and Protection, Medical College of Soochow University,

\begin{abstract}
Collaborative Innovation Center of Radiological Medicine of Jiangsu Higher Education Institutions, Suzhou 215123, China. ${ }^{3}$ Department of Nephrology, Second Hospital Lanzhou University Second Hospital, Lanzhou 730000, Gansu, China. ${ }^{4}$ Medical School, Northwest Min Zu University, Lanzhou 730030, Gansu, China.
\end{abstract}

Published online: 03 January 2022

\section{Reference}

1. Wang W, Hu W, Wang Y, et al. Long non-coding RNA UCA1 promotes malignant phenotypes of renal cancer cells by modulating the miR182-5p/DLL4 axis as a ceRNA. Mol Cancer. 2020;19:18. https://doi.org/10. 1186/s12943-020-1132-х.

The original article can be found online at https://doi.org/10.1186/s12943020-1132-x.

*Correspondence: shangpf@|zu.edu.cn; yuezhongjin@126.com

†Wei Wang, Wentao Hu and Ya Wang contributed equally to this work. 1 Department of Urology, Institute of Urology, Gansu Nephro-Urological Clinical Center, Key Laboratory of Urological Diseases in Gansu Province, Lanzhou University Second Hospital, Lanzhou 730030, Gansu, China

Full list of author information is available at the end of the article permits use, sharing, adaptation, distribution and reproduction in any medium or format, as long as you give appropriate credit to the original author(s) and the source, provide a link to the Creative Commons licence, and indicate if changes were made. The images or other third party material in this article are included in the article's Creative Commons licence, unless indicated otherwise in a credit line to the material. If material is not included in the article's Creative Commons licence and your intended use is not permitted by statutory regulation or exceeds the permitted use, you will need to obtain permission directly from the copyright holder. To view a copy of this licence, visit http://creativecommons.org/licenses/by/4.0/. The Creative Commons Public Domain Dedication waiver (http://creativeco mmons.org/publicdomain/zero/1.0/) applies to the data made available in this article, unless otherwise stated in a credit line to the data. 


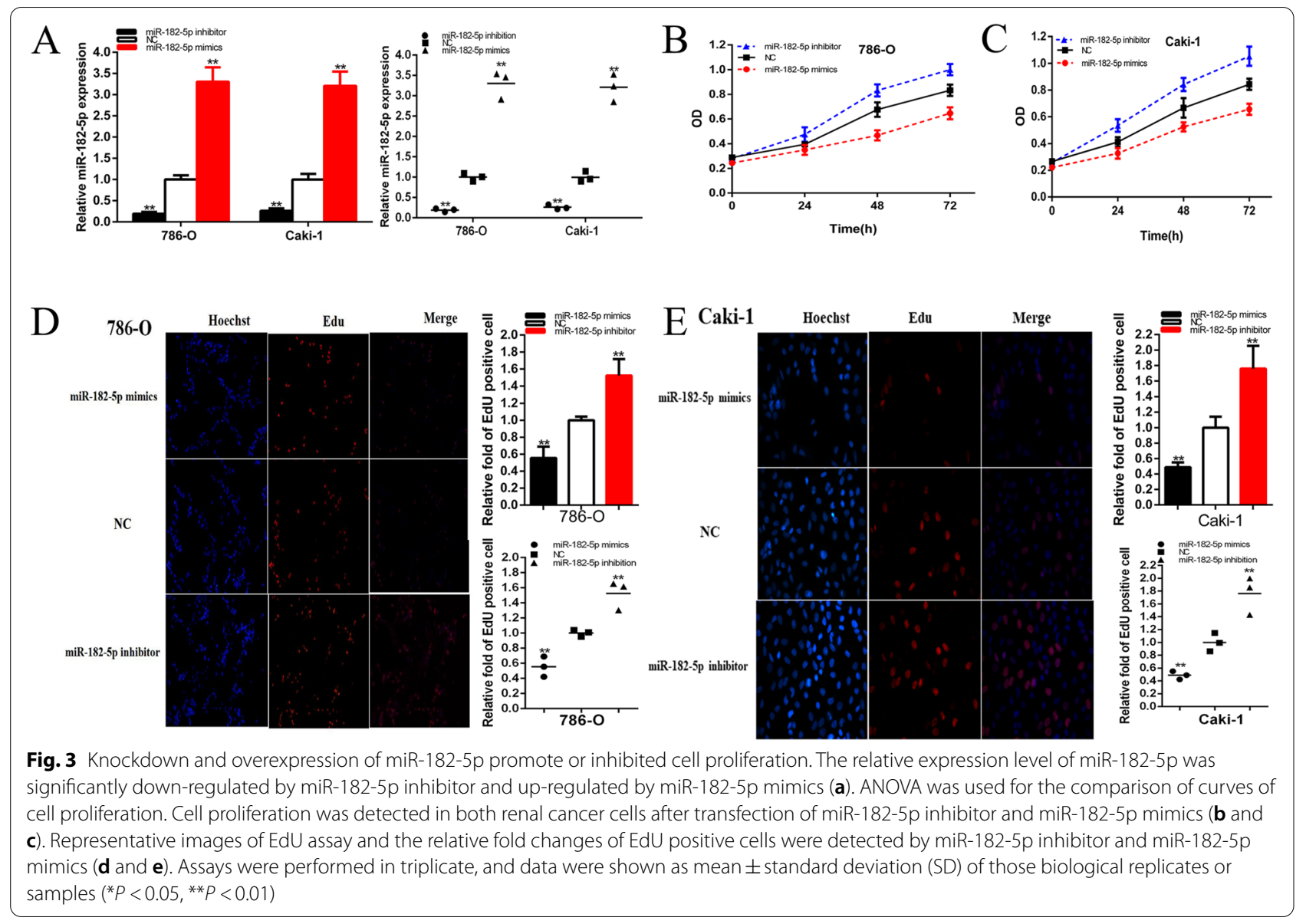




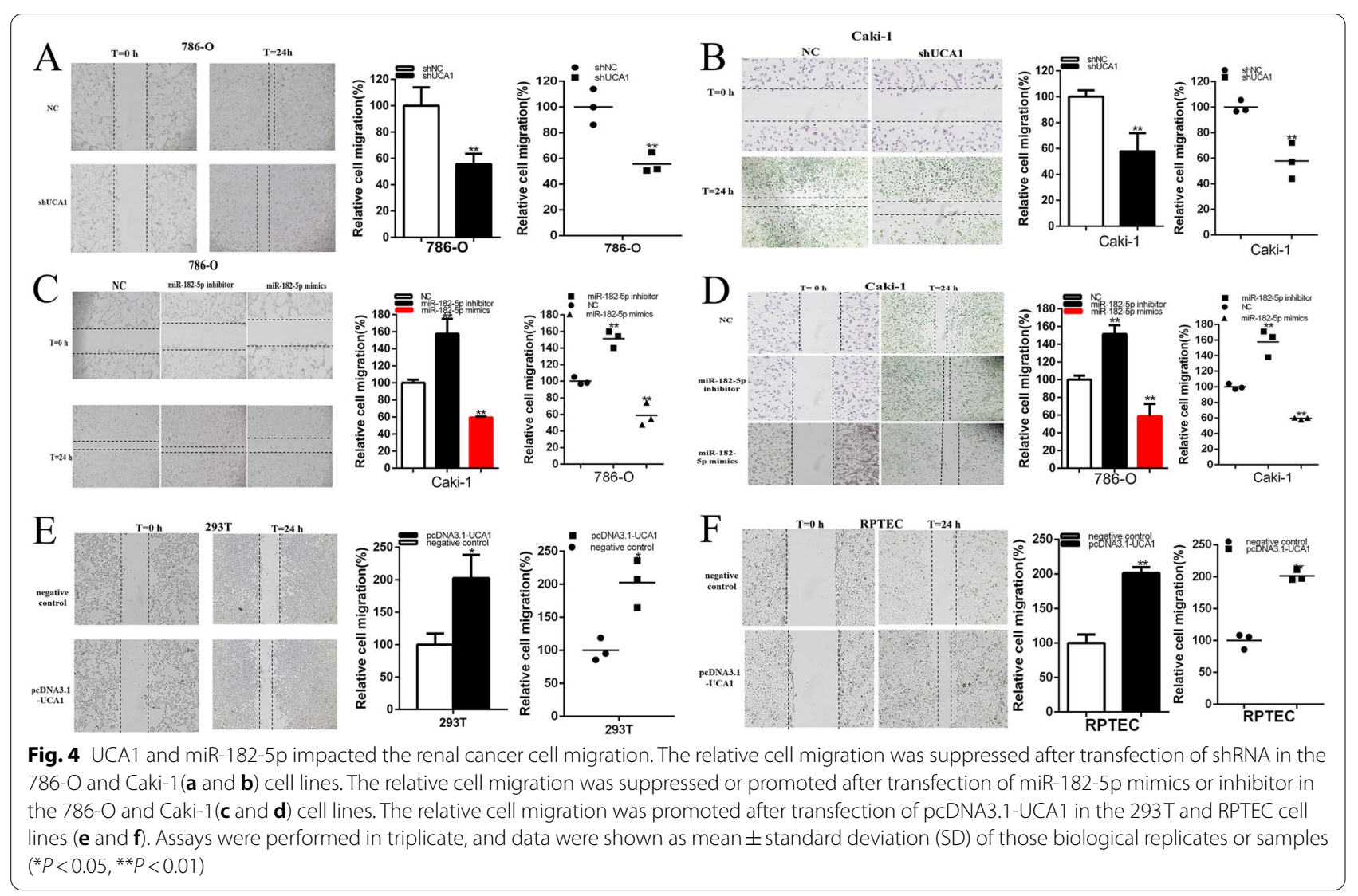




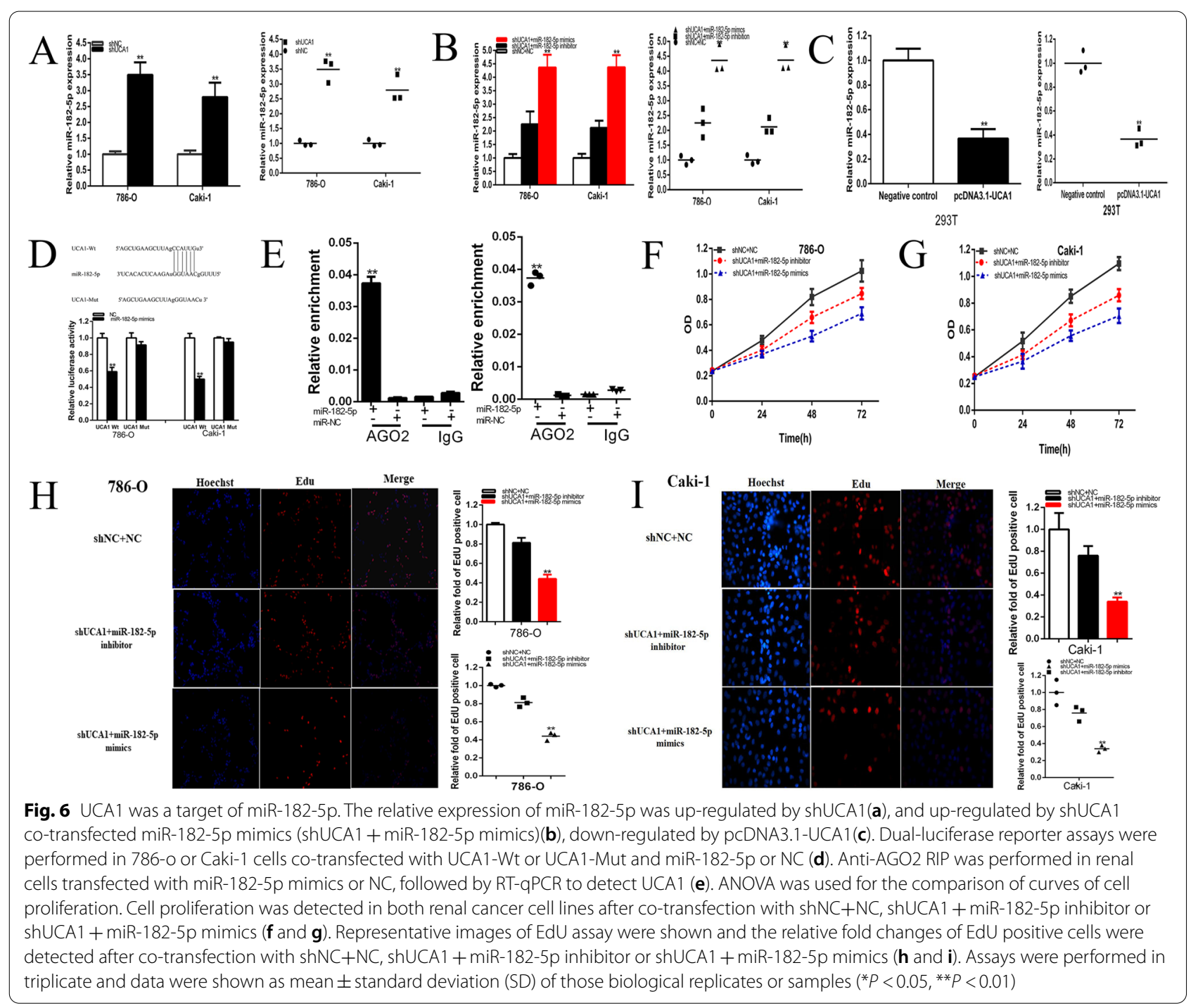

